\title{
IMPLEMENTASI PENILAIAN AUTENTIK KURIKULUM 2013 PADA MATA PELAJARAN PAI DAN BUDI PEKERTI DI SDN 1 BANGUNREJO PONOROGO
}

\author{
Mukhlas Habibi ${ }^{1}$, Fina Aulika Lestari ${ }^{1}$, Yusmicha Ulya Afif ${ }^{2}$ \\ ${ }^{1}$ UIN Sunan Kalijaga,Yogyakarta \\ ${ }^{2}$ Institut Agama Islam Negeri Ponorogo \\ *Corresponding Address: 20204011041.student@uin-suka.ac.id
}

Naskah diterima: 9 Desember 2021| Disetujui: 26 Desember 2021 | Diterbitkan: 27 Desember 2021

\begin{abstract}
Assessment is an important part of education, because with the assessment educators can see the extent to which the success of the learning process and the abilities of students. There are various types of assessments to measure students' abilities, in the 2013 curriculum there is an assessment model called authentic assessment. Authentic assessment is a comprehensive assessment that not only assesses students' cognitive mastery, but also assesses affective and psychomotor mastery. Educators who conduct authentic assessments of students will get the right assessment results, but sometimes there are still educators who use authentic assessments but are not in accordance with the competence of students. This study aims to reveal the problems that often occur, namely the discrepancy between the value and ability of students in mastering the subject matter. This research is a qualitative research. In the collection using observation techniques, interviews, and documentation.
\end{abstract}

Keywords: Authentic Assessment, Curriculum 2013, Islamic Education

\begin{abstract}
Abstrak: Penilaian merupakan bagian penting dalam pendidikan, sebab dengan adanya penilaian pendidik dapat melihat sejauh mana keberhasilan proses pembelajaran dan kemampuan peserta didik. Ada berbagai jenis penilaian untuk mengukur kemampuan siswa, dalam kurikulum 2013 terdapat model penilaian yang disebut penilaian autentik. Penilaian autentik adalah suatu penilaian yang komprehensif yang tidak hanya sekadar menilai penguasaan kognitif peserta didik, akan tetapi juga menilai tentang penguasaan afektif dan psikomotorik. Pendidik yang melakukan penilaian autentik terhadap peserta didik akan mendapatkan hasil penilaan yang tepat, namun terkadang masih ada pendidik yang menggunakan penilaian autentik namun tidak sesuai dengan kompetensi peserta didik. Penelitian ini bertujuan untuk mengungkap permasalahan yang sering terjadi, yaitu ketidaksesuaian antara nilai dan kemampuan siswa dalam menguasai materi pelajaran. Penelitian ini merupakan penelitian kualitatif. Teknik pengumpulan data menggunakan teknik observasi, wawancara, dan dokumentasi.
\end{abstract}

Kata kunci: Penilaian Autentik, Kurikulum 2013, Pendidikan Agama Islam 


\section{PENDAHULUAN}

Pendidikan merupakan aspek penting yang mempunyai pengaruh terhadap maju atau tidaknya peradaban suatu bangsa, sebab kemajuan bangsa ditentukan oleh salah satunya dengan mutu pendidikan (Baharudin, 2016). Pendidikan juga mempunyai pengaruh dalam membentuk dan meningkatkan kualitas masyarakat. Pendidikan merupakan jalan yang harus ditempuh dalam rangka mengembangkan SDM agar tercipta sumber daya manusia yang berkualitas melalui aspek pendidikan (Oemar, 2014). Seiring dengan perubahan zaman menuntut terjadinya perubahan pada bidang pendidikan. Pendidikan dituntut untuk bisa beradaptasi menyesuaikan perubahan tersebut. Berhasilnya pembelajaran sebagai bagian dari pendidikan apabila terdapat pegeseran sikap peserta didik yang menunjukkan kearah positif. Perubahan sikap yang demikian menandakan bahwa pendidikan dan pembelajaran yang dilaksanakan berhasil dan berkualitas.

Pembelajaran di kelas dikatakan berhasil apabila peserta didik mampu menguasai sejauh mana kompetensi yang diajarkan di dalam kelas. Secara garis besar, hasil belajar siswa dapat diklasifikasikan menjadi tigas aspek, yaitu aspek pengetahuan, aspek sikap, dan aspek keterampilan. Adanya penilaian dilaksanakan untuk mengevaluasi sistem pengajaran yang dilakukan dalam mencapai tujuan pembelajaran. Penilaian pembelajaran dalam arti sempit dimaknai sebagai cara untuk mengetahuai keberhasilan peserta didik dalam menguasai pelajaran, sedangkan dalam arti luas penilaian pembelajaran dimaknai sebagai cara untuk mengevaluasi berhasil atau tidaknya proses pembelajaran dalam mencapai tujuan pendidikan (Supardi, 2015).

Pendidik adalah salah satu unsur pokok dalam pendidikan. Seorang pendidik harus mampu memahami kurikulum yang menjadi jalan sekaligus rambu-rambu pelaksanaan pendidikan, termasuk di dalamnya ialah bentuk assesmen atau penilaian terhadap materi pelajaran yang disampaikan. Kurikulum hendaknya menjadi suatu tolak ukur kualitas proses dan output yang di dalamnya memuat gambaran pengetahuan, sikap, nilai, dan keterampilan lulusan. Untuk mengetahui kualitas lulusan perlu adanya suatu sistem penilaian yang tepat yaitu penilaian autentik atau authentic assessment (Majid, 2015).

Penilaian autentik adalah suatu penilaian komprehensif yang tidak sekedar menilai penguasan kognitif peserta didik, akan tetapi juga menilai tentang penguasaan afektif dan psikomotorik. Dalam pelaksanannya, penilaian autentik ini memerlukan berbagai macam teknik penilaian pada jenis aspek yang dinilai. Penilaian autentik yang sangat kompleks yang membuat sebagian diantara pendidik bekerja lebih keras dalam penggunaan jenis penilaian. Namun tak sedikit diantara para pendidik belum menguasai penilaian autentik ini, mereka hanya sekadar menilai aspek kognitif siswa dengan 
mengabaikan aspek afektif dan psikomotorik, sehingga banyak peserta didik mendaptakan nilai yang bagus pada laporan hasil belajar, namun kurang menguasai materi pelajaran (Kunandar, 2014).

Pendidikan agama Islam diartikan sebagai usaha yang terencana dalam membantu peserta didik supaya dalam menjalani kehidupan sesuai dengan syariat agama Islam. Dalam menghayati dan mengamalkan ajaran agama Islam tidak cukup hanya diajarkan, tetapi harus dilakukan dengan melewati sebuah proses pendidikan, sehingga tidak terbatas pada tataran teori akan tetapi dapat dipraktekkan dalam kehidupan sehari-hari. Pendidikan agama Islam mencakup pendidikan iman dan pendidikan amal (Lubna, 2014). Pendidikan agama Islam adalah merupakan suatu bentuk usaha yang dilakukan dalam rangka membina dan mengusahakan agar peserta didik supaya dapat memahami tuntunan syariat Islam secara komprehensif, kemudian menghayati tujuan akhir dengan mengamalkan serta menjadikan Islam sebagai pandangan hidup. Pendidikan agama Islam adalah usaha sadar untuk menyiapkan peserta didik dalam meyakini, memahami, menghayati, dan mengamalkan agama Islam melalui kegiatan bimbingan, pengajaran, dan/atau latihan dengan memperhatikan tuntutan menghormati agama lainnya dalam kerukunan antar umat beragama dalam masyarakat untuk mewujudkan persatuan nasional (Muhaimin, 2002).

Mata pelajaran Pendidikan Agama Islam yang dimaksud oleh penulis adalah mata pelajaran yang mencakup berbagai subtema untuk menyiapkan peserta didik dalam meyakini, memahami, menghayati, dan mengamalkan agama Islam dalam kehidupan sehari-hari. Mata pelajaran Pendidikan Agama Islam dan Budi Pekerti secara keseluruhannya dalam lingkup Al-Qur'an dan hadits, keimanan, akhlak, fiqih/ibadah dan sejarah, sekaligus menggambarkan bahwa ruang lingkup Pendidikan Agama Islam mencakup perwujudan keserasian, keselarasan, dan keseimbangan hubungan manusia dengan Allah SWT., diri sendiri, semua manusia, makhluk lainnya, maupun lingkungannya (hablum minallah wa hablum minannas).

Penelitian ini bertujuan untuk mengungkap permasalahan tentang keakuratan dan ketepatan suatu penilaian dalam mengukur kemampuan peserta didik dalam menguasai suatu pembelajaran serta sebagai evaluasi terhadap kualitas sistem pembelajaran.

\section{METODE}

Pendekatan yang digunakan dalam penelitian ini adalah pendekatan kualitatif. Adapun jenis penelitian ini adalah penelitian deskriptif kualitatif. Penelitian deskriptif kualitatif adalah penelitian yang menghasilkan data deskriptif berupa kata-kata tertulis atau lisan dari objek dan perilaku yang diamati (Sugiyono, 2017). Penilaian autentik yang digunakan pada mata pelajaran Pendidikan Agama Islam dan Budi Pekerti. Penilaian autentik adalah penilaian yang dilakukaan pada ranah 
pengetahuan, sikap, dan keterampilan. Pada ranah pengetahuan menggunakan teknik tes lisan, tes tertulis, dan penugasan. Pada ranah sikap menggunakan teknik observasi, penilaian natar teman, dan jurnal sebagai pendukung. Sedangkan pada ranah keterampilan menggunakan teknik unjuk kerja, proyek, potofolio, dan penilaian produk.

Pada penelitian ini pengumpulan data dan informasi peneliti menggunakan teknik observasi, wawancara, dan dokumentasi. Adapun untuk analisis data yaitu reduksi data, penyajian data, dan penarikan kesimpulan. Sedangkan teknik pemeriksaan keabsahan data menggunakan ketekunan pengamatan, trianggulasi, dan pemeriksaan teman sejawat melalui diskusi. Observasi, wawancara, dan dokumentasi dilakukan selama bulan September sampai November 2021 dengan mengamati pelaksanaan penilaian autentik di SD N 1 Bangunrejo Ponorogo. Wawancara dilakukan kepada guru PAI SD N 1 Bangunrejo terkait data penilaian autentik yang digunakan. Dokumentasi dilakukan dengan mengamati nilai hasil belajar peserta didik.

\section{HASIL DAN PEMBAHASAN}

\section{Penilaian Autentik}

Penilaian merupakan sinonim dari istilah kata pengukuran, pengujian, atau evaluasi. Assessment adalah sinonim dari penilaian, pengujian, dan evaluasi. Dalam kamus Bahasa Indonesia, kata evaluasi mempunyai arti penilaian (Pusat Informasi Balitbang Depdiknas. Undang-Undang Sisdiknas No.2 Tahun 2003). Sedangkan evaluasi dalam dunia pendidikan mempunyai arti yang berbeda. Penilaian merupakan bagian dari evaluasi. Menurut Zainal Arifin, evaluasi lebih luas ruang lingkupnya daripada penilaian, sedangkan penilaian lebih terfokus pada aspek tertentu saja yang merupakan bagian dari ruang lingkup tersebut (Arifin, 2013 ). Begitu juga dengan pengukuran yang sering disamakan dan dianggap bahwa pengukuran sama dengan evaluasi. Padahal pengukuran adalah suatu proses atau kegiatan untuk menentukan kuantitas sesuatu. Kata "sesuatu" bisa berarti peserta didik, guru, gedung sekolah, mejabelajar, white board dan sebagainya (Mulyasa E, 2006).

Penilaian merupakan istilah bahasa dari assessment, bukan dari istilah evaluation. Penilaian adalah kegiatan untuk memberikan berbagai informasi secara berkesinambungan dan menyeluruh tentang proses dan hasil yang telah dicapai peserta didik. Kata menyeluruh mengandung arti penilaian tidak hanya ditujukan pada penguasaan salah satu bidang tertentu saja, namun mencakup aspek pengetahuan, keterampilan, sikap dan nilai-nilai (Arifin, 2013). Sedangkan kata evaluasi dapat diartikan sebagai proses membandingkan situasi yang ada dengan kriteria tertentu dalam rangka mendapatkan informasi dan menggunakannya untuk menyusun penilaian dalam rangka membuat 
suatu keputusan. Evaluasi sebagai suatu proses penaksiran terhadap kemajuan, pertumbuhan, dan perkembangan peserta didik untuk tujuan pendidikan (Oemer, 2014).

Menurut Abdul Majid, penilaian autentik adalah proses pengumpulan berbagai data yang bisa memberikan gambaran perkembangan peserta didik (Majid, 2015). Sedangkan Supardi mengungkapkan bahwa authentik assesment adalah suatu assessment hasil belajar yang menuntut peserta didik menunjukkan prestasi dan hasil belajar berupa kemampuan dalam kehidupan nyata dalam bentuk kinerja atau hasil kerja (Supardi, 2015). Hamzah menjelaskan bahwa penilaian autentik atau autenthic assessment merupakan kegiatan menilai peserta didik yang memiliki titik fokus pada seharusnya yang menjadi untuk dinilai, baik proses maupun hasil dari berbagi instrument penilaian yang disesuaikan dengan tuntunan kompetensi yang termaktub dalam Standar Kompetensi Lulusan (SKL), kompetensi inti (KI) dan kompetensi dasar (KD) (Uno B Hamzah, 2012). Kurniasih menambahkan bahwa penilaian autentik merupakan suatu bentuk penilaian yang dijalankan untuk menilai, mulai dari masukan (input), proses, dan output pembelajaran yang melibatkan ranah sikap, pengetahuan, dan keterampilan (Majid, 2015; Uno B Hamzah, 2012).

Tujuan penilaian antara lain untuk mengetahui tingkat pencapaian kompetensi selama dan setelah proses pembelajaran berlangsung. Dengan demikian, kemajuan belajar peserta didik selama dan setelah proses pembelajaran dapat dideteksi sedini mungkin. Tujuan berikutnya adalah memberikan umpan balik bagi peserta didik agar mengetahui kekuatan dan kelemahannya dalam pencapaian kompetensi (Supardi, 2015). Hal ini dimaksudkan agar diperoleh informasi yang berkaitan dengan materi yang belum dikuasai dan materi yang sudah dikuasai siswa. Jika dibandingkan dengan pilihan ganda, Authentic Assesment lebih tepat sasaran (Supardi, 2015). Ketika menerapkan Authentic Assesment untuk mengetaui hasil dan prestasi belajar peserta didik, guru menerapkan kriteria yang berkaitan dengan kontruksi pengetahuan, aktivitas mengamati dan mencoba, serta nilai prestasi luar sekolah (Astuti, 2017; Kunandar, 2014).

Authentic Assesment terdiri atas beberapa teknik penilaian, yaitu pengukuran langsung keterampilan peserta didik, penilaian atas tugas-tugas yang memerlukan keterlibatan yang luas, analisis proses yang digunakan untuk menghasilkan respon peserta didik atas perolehan sikap, keterampilan dan pengetahuan yang ada (Muaizdati, 2019). Dengan demikian, Authentic Assesment akan bermakna bagi guru untuk menentukan cara-cara terbaik agar semua siswa dapat mencapai hasil akhir pembelajaran.

Dalam penerapan Authentic Assesment terdapat beberapa ciri dalam penilaian ini antara lain: (a) Harus mengukur semua aspek pembelajaran, yakni kinerja dan hasil atau produk (Sukiman, 2003). Artinya, dalam melakukan penilaian terhadap peserta didik harus mengukur aspek kinerja 
(performance) dan produk atau hasil yang dikerjakan oleh peserta didik. Dalam melakukan penilaian kinerja dan produk pastikan bahwa kinerja produk tersebut merupakan cerminan kompetensi dari peserta didik tersebut secara nyata dan objektif; (b) Dilaksanakan selama dan sesudah proses pembelajaran berlangsung. Artinya, dalam melakukan penilaian terhadap peserta didik, guru dituntut untuk melakukan penilaian terhadap kemampuan atau kompetensi peserta didik dalam kegiatan pembelajaran dan kemampuan atau kompetensi peserta didik setelah melakukan kegiatan pebelajaran; (c) Menggunakan berbagai cara dan sumber. Artinya, dalam melakukan penilaian terhadap peserta didik harus menggunakan berbagai teknik penilaian yang sesuai dengan tuntutan kompetensi dan menggunakan berbagai sumber atau data yang bisa digunakan sebagai informasi yang menggambarkan penguasaan kompetensi peserta didik; (d) Tes salah satu alat pengumpul penilaian. Artinya, dalam melakukan penilaian peserta didik terhadap pencapaian kompetensi tertentu harus secara komperhensif dan tidak hanya mengandalkan hasil tes semata. Informasi-informasi lain yang mendukung pencapaian kompetensi peserta didik dapat dijadikan bahan dalam melakukan penilaian; (e) Penilaian harus menekankan kedalaman pengetahuan dan keahlian peserta didik, bukan keluasannya (kuantitas). Artinya, dalam melakukan penialain peserta didik terhadap pencapaian kompetensi harus megukur kedalaman terhadap penguasaan kompetensi tertentu secara objektif (Kunandar, 2014).

Teknik penilaian hasil belajar secara umum dibedakan menjadi dua macam, yaitu teknik tes dan non tes. Teknik tes cocok digunakan untuk menilai hasil kognitif dan psikomotor. Teknis tes yang dapat digunakan untuk menilai hasil belajar kognitif adalah tes verbal baik yang berbentuk objektif maupun uraian (Kunandar, 2014; Majid, 2015). Hasil belajar psikomotor dalam pembelajaran Pendidikan Agama Islam dapat diukur dengan menggunakan tes penampilan atau kinerja, sedangkan pada instrumen untuk meperoleh datanya menggunakan skala penilaian dan daftar cek. Hasil belajar afektif adalah hasil belajar yang berkaitan dengan minat, sikap, dan nilaia-nilai. Teknik penilaian yang cocok untuk mengukur hasil belajar efektif adalah dengan teknik non tes (Majid, 2015). Ada beberapa bentuk penilaian non tes digunakan untuk menilai hasil belajar afektif, antara lain skala minat, skala sikap, pengamatan, wawancara, kuesioner/angket, biografi, dan anecdotal record (Sukiman, 2003).

Teknik dan instrumen penilaian kurikulum 2013 terdapat tiga macam, yakni penilaian kompetensi sikap, penilaian kompetensi pengetahuan, dan pengetahuan kompetensi keterampilan (Astuti, 2017). Pertama, penilaian kompetensi sikap merupakan teknik penilaian autentik untuk menilai peserta didik pada ranah sikap melalui observasi, penilaian diri, dan penilaian teman sejawat (peer review) oleh peserta didik dan jurnal. Sedangkan instrumen yang digunakan dalam penilaian kompetensi sikap ini adalah menggunakan daftar cek atau skala penilaian yang disertai rubrik, adapun 838 
pada jurnal berupa catatan pendidik. Kedua, penilaian kompetensi pengetahuan. Penilaian pada kompetensi kognitif atau pengetahuan dapat dilakukan melalui tes tertulis, tes lisan, dan penugasan. Ketiga, adalah penilaian kompetensi keterampilan. Penilaian pada ranah kompetensi keterampilan atau psikomotorik dapat dilakukan melalui penilaian kinerja, yakni suatu macam penilaian yang menuntut peserta didik untuk memperagakan suatu kompetensi tertentu dengan menggunakan tes praktik, tes project, dan penilaian portofolio. Sedangkan intrumen yang digunakan adalah daftar cek atau sekala penilaian yang dilengkapi dengan rubrik (Kunandar, 2014; Supardi, 2015).

\section{Penilaian Aspek Sikap}

Menurut Reynolds, Livington, dan Wilson sikap adalah karakter seseorang tentang bagaimana berfikir, bertindak, dan perasaan. Aktivitas yang dilakukan oleh pendidik dalam rangka untuk mendapatkan informasi terhadap peserta didik sebagai bagian dari langkah penilaian sikap. Penilaian sikap dilaksanakan dengan menitik beratkan pada kecenderungan perilaku peserta didik yang merupakan hasil dari pendidikan yang telah dialami baik dalam kelas atau di luar kelas (Retnawati, 2017).

Sikap merupakan bentuk kesadaran dari manusia dalam menentukan perbuatan dalam kenyataan kehidupan sehari-hari. Kurikulum 2013 sebagai kurikulum yang mengutamakan pendidikan karakter. Pengembangan karakter sangatlah penting seperti halnya pengembangan pengetahuan peserta didik, sehingga dalam kenyataannya akan ditemui perbedaan sikap dari satu manusia denga manusia yang lain (Tiara, Shintia, 2019). Kurikulum 2013 mempunyai tujuan pendidikan karakter membangun masyarakat menjadi manusia yang berakhlak mulia, manusia yang baik, membentuk dan membangun sikap, pola pikir, perilaku dari peserta didik agar menjadi pribadi yang positif, bertanggung jawab, berjiwa luhur, dan berakhlakul karimah (Muaizdati, 2019).

Sikap spiritual merupakan perwujudan hubungan antara manusia dengan sang pencipta, sedangkan sikap sosial adalah gambaran hubungan antara manusia dengan manusia atau manusia dengan lingkungan sekitarnya. Sikap sosial juga bisa dikatakan sebagai kesadaran individu dalam menentukan perbuatan nyata yang berulang-ulang terhadap objek sosial. Dapat dikatakan bahwa sangat penting sikap sosial yang harus dimiliki oleh siswa, karena kehidupan sehari-hari dipengaruhi oleh sikap, baik sikap orang lain atau bahkan sikap terhadap diri sendiri.

Proses berfikir dalam ranah sikap menurut Kunandar terbagi menjadi lima jenjang. Pertama, menerima atau memerhatikan. Hal ini lebih mengacu pada kemauan individu untuk lebih memperhatikan kejadian atau rangsangan tertentu, menerima termasuk tingkatan terendah dalam ranah afektif. Kedua, merespon atau menanggapi. Pada tingkat ini individu tidak hanya mengikuti fenomena yang terjadi akan tetapi sudah ke tahap turut bereaksi terhadap fenomena tersebut 
(Kunandar, 2014). Ketiga, menilai atau menghargai. Tahap ini merupakan perwujudan nilai seseorang terhadap objek fenomena atau perilaku tertentu, tingkat ini adalah proses dari penerimaan nilai yang terhitung sederhana ke tingkat komitmen yang lebih kompleks. Keempat, mengorganisasi atau mengelola. Tahap keempat ini merupakan tahap yang memiliki keterkaitan yang bertujuan menyatukan kepentingan nilai yang berbeda, menyelesaikan konflik secara internal serta memulai pembangunan sistem nilai yang konsisten. Kelima, berkarakter. Setiap individu memiliki sistem nilai yang mampu mengendalikan perilakunya dalam kurun waktu yang cukup lama (Mauizdati, 2019).

Teknik penilaian sikap pertama adalah observasi. Teknik penilaian observasi dilakukan secara berkesinambungan dengan memakai indra, baik secara langsung maupun secara tidak langsung, serta melihat dari indikator perilaku yang diamati sudah tercantum di pedoman observasi (Astuti, 2017). Teknik utama yang diperlukan dalam penilaian sikap adalah teknik observasi. Pada dasarnya setiap peserta didik memiliki perilaku sikap yang baik, sehingga yang perlu dicatat dalam penilaian sikap hanya perilaku yang sangat baik atau perilaku kurang baik. Catatan diberikan pada peserta didik berkaitan dengan hal-hal positif yang berguna untuk menguatkan perilaku positif, lain halnya dengan perilaku negatif peserta didik digunakan sebagai pembinaan (Supardi, 2015). Lembar observasi dan jurnal adalah bagian dari instrumen yang digunakan dalam penilaian sikap menggunakan teknik observasi. Guru mata pelajaran, guru BK, serta wali kelas membuat catatan yang dimuat dalam jurnal untuk merangkum hasil observasi yang dilakukan selama satu semester. Dalam jurnal tersebut berisikan tentang catatan penilaian sikap peserta didik yang sangat baik atau bahkan kurang baik dilengkapi dengan butir-butir sikap dan waktu kapan terjadinya perilaku peserta didik tersebut. Dengan demikian, pendidik dapat mendeskripsikan penilaian sikap terhadap peserta didik berdasarkan catatan tersebut (Retnawati, 2017).

Teknik penilaian sikap kedua adalah penilaian diri. Dalam konteks pencapaian kompetensi, pendidik meminta peserta didik untuk mengutarakan kelebihan dan kekurangan yang dimiliki oleh masing-masing peserta didik yang disebut dengan penilaian diri. Instrumen yang dipakai adalah lembar penilaian diri (Muaizdati, 2019). Penilaian diri yang dilakukan oleh peserta didik minimal satu kali dalam satu semester, peraturan tersebut disebutkan dalam panduan penilaian pada sekolah menengah kejuruan dan panduan penilaian pada sekolah menengah atas (Kunandar, 2014). Peserta didik dapat melakukan refleksi dari kualitas pekerjaan yang telah dikerjakan, lalu membandingkan seberapa besar kualitas tercapainya pekerjaan dengan kriteria yang telah ditentukan, serta mampu melakukan perbaikan terhadap pembelajarannya sendiri. Ketiga hal tersebut menunjukkan penilaian diri sebagai suatu proses penilaian yang bersifat formatif (Retnawati, 2017). Penilaian diri bertujuan untuk memberikan kesempatan peserta didik agar mampu memberikan penilaian terhadap dirinya sendiri, dengan begitu peserta didik bisa mengetahui dan menyadari sejauh mana sikap jujur sikap 
yang dimilikinya. Hal itu juga bisa digunakan sebagai salah satu instrumen untuk melatih kejujuran peserta didik (Winarni, 2017).

Teknik penilaian sikap ketiga adalah penilaian antar teman. Penilaian antar teman merupakan teknik penilaian dengan cara meminta peserta didik untuk saling menilai terkait dengan sikap dan perilaku keseharian peserta didik yang lain, penilaian ini menggunakan instrumen lembar penilaian antar peserta didik (Tiara, Shintia, 2019). Penilaian antar teman ini juga memiliki tujuan memberikan kesempatan peserta didik untuk ikut andil dalam menilai, khususnya dalam menilai sikap peserta didik yang lainnya. Namun dalam penilaian ini tidak sedikit kendala yang dirasakan, salah satu kendalanya adalah rasa tidak enak dalam penilaian temannya jika harus menilai dengan apa adanya, padahal dalam pendidikan harus menggunakan asas jujur dan objektif (Winarni, 2017).

Penilaian antar teman sama halnya dengan penilaian diri, kedua penilaian ini hanya bersifat sebagai penunjang teknik penilaian utama (observasi), data yang dihasilkan hanya sebagai alat konfirmasi dari hasil observasi (Kunandar, 2014). Ada beberapa faktor pendorong mengapa penilaian antar teman perlu dilakukan, menurut Race dan Bostock mengidentifikasi kelebihan-kelebihan dari penilaian antar teman. Pertama, bisa memperbaiki proses pembelajaran. Kedua, pengidentifikasian kelemahan dan kekuatan yang dimiliki dalam belajar oleh peserta didik. Ketiga, ada dorongan agar peserta didik mampu belajar lebih mendalam dan penuh makna. Keempat, mendorong peserta didik agar belajar mandiri. Kelima, mendorong peserta didik untuk saling menganalisis unjuk kerja atau hasil kerja masing-masing peserta didik. Merujuk pada panduan penilaian yang dikeluarkan oleh pemerintah (kemendikbud 2015) dalam penilaian antar teman dilakukan ketika peserta didik melakukan kegiatan kelompok, sebagai contoh setiap peserta didik diminta untuk menilai atau mengamati dua orang temannya, begitupun sebaliknya (Retnawati, 2017).

Teknik penilaian sikap keempat adalah jurnal. Teknik ini merupakan teknik penilaian di mana pendidik memberikan catatan hasil penilaian baik di dalam kelas maupun di luar kelas. Catatan tersebut berisi informasi hasil pengamatan yang dilakukan pendidik tentang kekuatan dan kelemahan yang dimiliki oleh peserta didik baik sikap maupun perilaku (Majid, 2015; Winarni, 2017). Catatan dalam jurnal sikap adalah perilaku yang dilakukan oleh peserta didik selama satu semester yang berkaitan erat dengan sikap spiritual seperti melaksanakan salat berjama'ah, doa sebelum atau sesudah melakukan pekerjaan, dan contoh sikap yang lain yang berkaitan dengan sikap spiritual. Sikap sosial juga harus dimuat dalam jurnal sikap untuk menyajikan catatan perilaku yang berkaitan dengan pergaulan dengan sesama teman ataupun dengan guru. Data yang dimuat dalam jurnal akan memberikan kemudahan guru dalam proses mengidentifikasi peserta didik dalam berperilaku pada kehidupan sehari-har. Data yang termuat dalam jurnal akan memberikan gambaran sikap peserta 
didik, kumpulan dari sikap-sikap tersebut kemudian diolah untuk menjadi nilai sikap spiritual dan sikap sosial yang dicantumkan pada rapor (Winarni, 2017).

\section{Penilaian Aspek Pengetahuan}

Penilaian pengetahuan sesuai permendikbud Nomor 23 Tahun 2016 merupakan kegiatan yang dilakukan untuk mengukur penguasaan pengetahuan peserta didik. Kompetensi pengetahuan peserta didik dinilai meliputi kemampuan faktual, konseptual, prosedural, metakognitif, serta kecakapan berfikir tingkat rendah sampai berfikir tingkat tinggi, dari mengingat, memahami, menerapkan, menganalisis, mengevaluasi, dan menciptakan. Penilaian kompetensi pengetahuan berkaitan dengan kompetensi dasar pada KI-3 yang dilakukan oleh guru mata pelajaran, satuan pendidikan, maupun pemerintah. Penilaian pengetahuan dilakukan dengan berbagai teknik penilaian (Majid, 2015; Uno B Hamzah, 2012).

Pendidik menetapkan teknik penilaian sesuai dengan karakteristik kompetensi yang akan dinilai. Penilaian dimulai dengan perencanaan pada saat menyusun Rencana Pelaksanaan Pembelajaran (RPP) yang mengacu pada silabus. Penilaian pengetahuan selain ditunjukkan untuk mengetahui apakah peserta didik telah mencapai ketuntasan belajar, juga untuk mengindentifikasi proses pembelajaran (Hamzah, 2012). Artinya, penilaian pengetahuan berfungsi sebagai diagnostik kemampuan kognitif peserta didik. Oleh karena itu, pemberian umpan balik (feedback) kepada peserta didik merupakan hal yang sangat penting, sehingga hasil penelitian dapat segera digunakan untuk perbaikan mutu pembelajaran. Ketuntasan belajar untuk pengetahuan ditentukan oleh satuan pendidikan dengan mempertimbangkan batas standar minimal nilai satuan pendidikan dan meningkatkan kriteria ketuntasan belajar dengan mempertimbangkan potensi dan krakteristik masing-masing satuan pendidikan sebagai bentuk peningkatan kualitas hasil belajar (Supardi, 2015; Hamzah, 2012).

Tabel 1.Tingkat Kemampuan Berfikir Kompetensi Pengetahuan

\begin{tabular}{ccl}
\hline No & Description & \multicolumn{2}{c}{ Explanation } \\
\hline 1 & Mengingat & Mengungkapkan kembali pengetahuan yang \\
& & sudahpernah dipelajari peserta didik dari ingatan \\
& & yang diperoleh dari berbagai sumber baik itu guru \\
& \multirow{2}{*}{ Memahami } & ataupun sumber belajar lain. \\
& & Mengonstruksi makna dari tujuan pembelajaraN \\
& & yang disampaikan secara lisan oleh guru, tertulis atau \\
& berdasarkan informasi dari grafik atau gambar. \\
\hline
\end{tabular}




\begin{tabular}{|c|c|c|}
\hline 3 & Menerapkan & $\begin{array}{l}\text { Menggunakan konsep, prosedur ataupun prinsip } \\
\text { yang sudah dipelajari pada situasi tertentu dalam } \\
\text { menyelesaikan masalah. }\end{array}$ \\
\hline 4 & Menganalisis & $\begin{array}{l}\text { Mengelompokkan informasi yang diperoleh kedalam } \\
\text { materi-materi pokok dan menentukan keterkaitan } \\
\text { ataupun hubungan informasi-informasi tersebut } \\
\text { dengan informasi atau konsep lain. }\end{array}$ \\
\hline 5 & Mengevaluasi & $\begin{array}{l}\text { Menilai dan membuat keputusan dari informasi yang } \\
\text { diperoleh berdasarkan kriteria dan standar acuan }\end{array}$ \\
\hline 6 & Mencipta & $\begin{array}{l}\text { Membuat sesuatu yang baru fungsional utuh dari } \\
\text { berbagai informasii dan menyusun inormasi yang } \\
\text { diperoleh menjadi inormasi pola atau struktut baru }\end{array}$ \\
\hline
\end{tabular}

Enam tingkatan pada tabel di atas itulah yang sering digunakan dalam merumuskan tujuan belajar yang di kenal dengan istilah C1 sampai dengan C6.

Tabel 2. Dimensi Pengetahuan

\begin{tabular}{|c|c|c|}
\hline No & Description & Explanation \\
\hline 1 & Faktual & $\begin{array}{l}\text { Pengetahuan mendasar yang harus diketahui peserta } \\
\text { didik yang terkait dengan disiplin ilmu atau mata } \\
\text { pelajaran yang dipelajari yang mencakup } \\
\text { penegtahuan terminologi dan termasuk didalamnya } \\
\text { pengetahuan untuk menyelesaikan masalah. }\end{array}$ \\
\hline 2 & Konseptual & $\begin{array}{l}\text { Pengetahuan tentang kategori, klasifikasi,keterkaitan } \\
\text { antara konsep dasar dengan struktur lainnya, prinsip, } \\
\text { teori, model, struktur dangeneralisasi. }\end{array}$ \\
\hline 3 & Prosedural & $\begin{array}{l}\text { Pengetahuan tentang bagaimana dalam } \\
\text { menyelesaikan masalah, metode penemuan, dan } \\
\text { kriteria untuk menggunakan keterampilan,akgoritma, } \\
\text { teknik, dan metode untuk menyelesaikan masalah. }\end{array}$ \\
\hline 4 & Metakognitif & $\begin{array}{l}\text { Pengetahuan tentang cara mempelajari pengetahuan, } \\
\text { menentukan pengetahuan yang penting dan tidak } \\
\text { penting, pengetahuan yang sesuai dengan konteks } \\
\text { tertentu dan pengetahuan diri. }\end{array}$ \\
\hline
\end{tabular}

Terdapat tiga teknik penilaian ranah pengetahuan. Pertama, adalah tes tertulis, yaitu tes dengan soal dan jawaban yang disajikan secara tertulis untuk mengukur atau memperoleh informasi tentang kemampuan peserta didik. Penilaian tertulis digunakan untuk menilai kompetensi keterampilan seperti menulis. Sedangkan rubrik penilaian disesuaikan dengan mata pelajaran masing-masing. Penilaian tes tertulis dengan bentuk instrumen soal pilihan ganda, isian jawaban singkat 
mencocokkan, benar salah, ataupun bentuk instrumen uraian (Supardi, 2015). Hal yang perlu diperhatikan ketika melaksanakan penilaian pengetahuan menggunakan teknik tes tertulis ialah representasi kompetensi dasar yang diukur, pertanyaan yang memiliki kunci jawaban sekaligus rubrik penskoran dan disusun berdasarkan indikator kata kerja operasional C1 sampai dengan C6 (Taksonomi Bloom-Krathwohl). Dalam teknik penilaia tes tertulis terdapat beberapa instrumen penilaian, yaitu jawaban singkat, benar salah, mencocokkan, pilihan ganda, uraian, dan essay (Astuti, 2017).

Kedua, adalah teknik penilaian tes lisan yang merupakan pemberian soal atau pertanyaan yang menuntut peserta didik menjawab secara lisan dan dapat diberikan secara klasikal saat pembelajaran. Jawaban peserta didik dapat berupa kata, frase, kalimat, maupun paragraf. Tes lisan menumbuhkan sikap peserta didik untuk berani berpendapat. Meskipun teknik tes lisan disampaikan atau ditanyakan kepada peserta didik secara langsung tanpa menuliskannya pada kertas, tetapi bukan berarti tes lisan dilakukan secara mendadak dan tanpa persiapan (Majid, 2015; Muaizdati, 2019).

Ketiga, adalah bentuk penilaian penugasan. Teknik penugasan dapat diberikan dalam bentuk pekerjaan rumah ataupun proyek sesuai dengan indikator pengetahuan yang akan dinilai (Majid, 2015). Penugasan merupakan kegiatan pemberian tugas kepada peserta didik untuk mengukur dan untuk meningkatkan pengetahuan. Penugasan dapat dilakukan saat proses pembelajaran maupun setelah proses pembelajaran berlangsung (Retnawati, 2017).

\section{Penilaian Aspek Keterampilan}

Penilaian keterampilan adalah penilaian yang dilakukan untuk menilai kemampuan peserta didik dalam menerapkan pengetahuan. Selain itu, melakukan tugas tertentu pada berbagai macam konteks sesuai dengan indikator pencapaian kompetensi. Keterampilan dibagi menjadi dua, yaitu keterampilan abstrak dan keterampilan konkret. Keterampilan abstrak merupakan kemampuan belajar yang meliputi mengamati, menanya, mengumpulkan informasi/mencoba, menalar/mengasosiasi, dan mengkomunikasikan. Keterampilan konkret meliputi persepsi, kesiapan, meniru, membiasakan, dan mahir (Majid, 2015; Supardi, 2015). Permendikbud No 14 tahun 2014 tentang standar penilaian pendidik menilai kompetensi keterampilan melalui penilaian kinerja, yaitu penilaian yang menuntut peserta didik mendemonstrasikan suatu kompetensi tertentu dengan menggunakan tespraktik, proyek, produk, dan portofolio.

Terdapat tiga teknik yang digunakan dalam penilaian pada ranah keterampilan. Pertama, penilaian unjuk kerja, yaitu penilaian dengan cara mengamati kegiatan siswa dalam menerapkan suatu pekerjaan atau kegiatan. Penilaian unjuk kerja/kinerja/praktik biasa digunakan untuk mengetahui ketercapaian kompetensi yang mengharuskan peserta didik melakukan aktivitas atau tugas tertentu 
seperti melakukan salat, membaca puisi menggunakan intonasi, membaca beberapa surat pendek AlQur'an, praktek olah raga, berpidato, dan lain sebagainya (Kunandar, 2014).

Kedua, penilaian proyek, yaitu penilaian yang diperoleh siswa dalam menyelasaikan tugas dalam waktu tertentu. Hal ini dilakukan untuk mengukur siswa dalam memahami suatu penyelidikan. Dalam penilaian ini mencakup perencanaan, pengorganisasian, mengumpulkan data, mengolah data, memiliki kemampuan menyelidiki, hingga melaporkan hasil penyelidikan. Tahapan dalam penilaian proyek, yaitu perencanaan, pelaksanaan, dan melaporkan (Majid, 2015).

Ketiga, penilaian produk, yaitu penilaian yang ditinjau dari karya yang dibuat oleh peserta didik seperti karya seni, membuat kerajinan dari tanah liat (patung), kaligrafi, dan lukisan. Kemudian membuat alat kebersihan seperti sapu, sabun, dan pewangi pakaian. Selain itu juga dapat membuat produk makanan seperti tape, tempe, bakso dan lain sebagainya. Ada juga yang berasal dari teknologi seperti bel listik, pemotong rumput, dan lainya (Supardi, 2015).

Penilaian portofolio adalah penilaian yang berupa rekaman hasil dari proses pembelajaran juga dapat memperkuat kemajuan dan mempertinggi kualitas pekerjaan siswa. Pada dasarnya penilaian portofolio ditinjau dari karya-karya peserta didik secara individu pada satu periode. Penilaian tersebut dinilai oleh guru maupun peserta didik itu sendiri. Dari penilaian satu periode guru dan peserta didik dapat melihat dan menilai perkembangannya, sehingga akan dilakukan perbaikan (Kunandar, 2014; Supardi, 2015). Dengan adanya penilaian portofolio, guru dan peserta didik dapat mengetahui naik turunnya kemampuan belajar.

Berdasarkan Permendikbud No.104 Tahun 2014 tentang penilaian prestasi belajar oleh guru pada pendidikan dasar dan pendidikan menengah bagian pedoman penilaian prestasi belajar melampirkan prinsip-prinsip penilaian autentik, di antaranya (a) materi penilaian dikembangkan dari kurikulum, (b) bersifat lintas muatan atau mata pelajaran, (c) berkaitan dengan kemampuan peserta didik, (d) berbasis kinerja peserta didik, (e) memotivasi belajar peserta didik, (f) menekankan pada kegiatan dan pengalaman belajar peserta didik, (g) memberi kebebasan peserta didik untuk mengkonstruksi responnya, (h) menekankan keterpaduan sikap, pengetahuan, dan keterampilan, (i) mengembangkan kemampuan berpikir divergen, (j) menjadi bagian yang tidak terpisahkan dari pembelajaran (k) menghendaki balikan yang segera dan terus menerus, (l) menekankan konteks yang mencerminkan dunia nyata, (m) terkait dengan dunia kerja, (n) menggunakan data yang diperoleh langsung dari dunia nyata, (o) menggunakan berbagai cara dan instrument (Astuti, 2017; Muaizdati, 2019).

Prinsip penilaian autetik pada jenjang pendidikan dasar dan menengah pada kurikulum 2013 adalah objektif atau berdasarkan standar penilaian dan tidak dipengaruhi subjektivitas penilai, terpadu 
atau dilakukan sesuai rencana dengan kegiatan pembelajaran dan berkesinambungan, ekonomis dengan penilaian yang efektif dan efisien dalam perencanaan, pelaksanaan dan pelaporannya, serta transparan atau prosedur penilaian kriteria penilaian dan dasar pengambilan penilaian dapat dijangkau oleh semua pihak. Selain itu juga harus akuntabel, yakni penilaian dapat dipertanggungjawabkan kepada pihak internal sekolah maupun eksternal di luar sekolah untuk teknik, prosedur, dan hasilnya. Terakhir adalah edukatif, bersifat mendidik, dan memotivasi peserta didik (Majid, 2015).

Authentic Assesment dalam mata pelajaran Pendidikan Agama Islam adalah kegiatan dalam menilai peserta didik yang menekankan yang seharusnya dinilai, baik proses maupun hasil dengan berbagai instrumen, penilaian yang disesuaikan dengan tuntutan kompetensi ajaran Islam dan bisa diterapkan dalam kehidupan sehari-hari. Penilaian mata pelajaran Pendidikan Agama Islam di sekolah dilakukan terhadap semua aspek. Aspek pokok dari penilaian meliputi pengetahuan agama Islam, keterampilan agama Islam, penghayatan agama Islam, dan pembiasaan serta pengamalan agama Islam. Dalam penerapan penilaian autentik pembelajaran dikaitkan dengan keseharian peserta didik. Guru mengaitkan materi dengan kenyataan dilingkungan masyarakat. Guru tidak terpaku pada buku teks melainkan kreatif mencari bahan belajar dari koran, majalah, atau internet (J Musfah, 2017).

Penilaian autentik sangat bagus diterapkan dalam pembelajaran Pendidikan Agama Islam karena dengan adanya penilaian autentik, guru dapat melatih peserta didik menerapkan secara langsung materi yang diajarkan dikehidupan sehari-hari dan dapat menilai sikap peserta didik setelah belajar materi tersebut. Contohnya, pada materi ibadah tentang haji. Pada materi haji ini guru dapat membawa peserta didik melakukan kegiatan manasik haji dengan menggunakan media seperti ka'bah buatan, sehingga peserta didik dapat merasakan dengan nyata bagaimana melaksanakan ibadah haji, dan juga menerapkan pengetahuan yang telah diajarkan tentang ibadah haji (J Musfah, 2017; Nurhadi, 2004).

Karakteristik dari penilaian autentik meliputi beberapa aspek. Pertama, keterlibatan peserta didik dalam pengalaman nyata yang dilaluinya. Kedua, dilakukan dalam jangka waktu pada saat dan sesudah proses pembelajaran berlangsung. Ketiga, termasuk penilaian pribadi (self assessment) dan refleksi yang diukur melalui keterampilan dan pengalaman. Keempat, dilakukan secara terus menerus atau berkelanjutan. Kelima, adalah terintegrasi. Keenam, adalah berfungsi sebagai umpan balik. Ketujuh, indikator keberhasilan dan kegagalan diketahui oleh peserta didik dengan jelas (Nurhadi, 2004).

Makna dilakukannya penilaian agar mengetahui sejauh mana siswa telah berhasil mengikuti pelajaran dan kompetensi apa saja yang sudah tercapai selama siswa mengikuti kegiatan belajar 
mengajar. Guru juga akan mengetahui siswa yang dapat melanjutkan tahapan materi pelajarannya, sebab sudah memenuhi Kriteria Ketuntasan Minimal (KKM), dan juga untuk mengetahui materi pelajaran yang diajarkan oleh pendidik apakah telah sesuai dengan siswa, serta untuk mengetahui strategi, metode, dan pendekatan yang digunakan sudah sesuai. Adapun untuk sekolah berguna untuk mengetahui penilaian yang dilakukan oleh guru apakah telah sesuai dengan kondisi belajar dan kultur akademik sekolah, informasi penilaian dapat menjadi bahan acuan evaluasi Sandar Nasional Pendidikan, dan informasi penilaian dapat menjadi bahan acuan bagi sekolah untuk menyusun rencana pendidikan yang mendatang agar lebih baik (Widoyoko, 2013).

\section{Kurikulum 2013}

Manusia berkualitas adalah manusia yang memiliki kemampuan akademis yang bagus, cerdas, intelektual, dan memiliki kualitas dalam membina hubungan sesama manusia dan sesama makhluk Tuhan. Perguruan Tinggi seolah sebagai pabrik yang diharapkan dapat menghasilkan lulusan sarjana yang professional. Tidak hanya memiliki wawasan yang luas akan tetapi juga beriman dan bertaqwa kepada Tuhan Yang Maha Esa, serta memiliki rasa soslidarits tinggi terhadap sesama (Dirjen Perguruan Tinggi Agama Islam, 1998). UU nomor 20 tentang Sistem Pendidikan Nasional tahun 2003 pada pasal 3 menyebutkan bahwa Pendidikan Nasional berfungsi mengembangkan kemampuan, membentuk watak, serta peradaban bangsa yang bermartabat dalam rangka mencerdaskan kehidupan bangsa bertujuan untuk berkembangnya potensi peserta didik agar menjadi manusia yang beriman dan bertaqwa kepada Tuhan Yang Maha Esa, berakhlak mulia, sehat, berilmu, cakap, kreatif, mandiri, menjadi warga negara yang demokratis, dan bertanggung jawab (Pusat Informasi Balitbang Depdiknas. Undang-Undang Sisdiknas No.2 Tahun 2003).

Kurikulum berasal dari bahasa Yunani yang pada awalnya digunakan dalam bidang olah raga yaitu jarak tempuh dalam berlari yang disebut curere. Curere inilah sebutan untuk jarak yang ditempuh oleh pelari dari start hingga finish (Muhadjir Neong, 1996). Secara istilah kurikulum adalah seperangkat rencana dan pengaturan mengenai tujuan, kompetensi dasar, materi standar, hasil belajar, dan cara yang digunakan sebagai pedoman penyelenggara kegiatan pemebelajaran dalam mencapai hasil kompetensi dasar dan tujuan pendidikan (Mulyasa E, 2006).

Negara Indonesia telah melakukan perubahan kurikulum sebanyak sembilan kali, mulai dari kurikulum tahun 1947 dengan istilah rentjana pelajaran sampai kurikulum 2013 yang menekankan pada pendidikan karakter. Perubahan ini dilakukan sebagai respon terhadap perubahan dan tantangan zaman yang selalu berkembang. Pada setiap model kurikulum yang digunakan memiliki karakteristik yang berbeda dengan model kurikulum yang lain. Termasuk pada kurikulum 2013 memiliki karakteristik penekanan pada nilai karakter peserta didik, sehingga muncul model penilaian autentik 
yang relevan dengan karakter kurikulum 2013 pada penilaian autentik. Penilaian pada peserta didik tidak hanya berorientasi pada output, tapi juga memperhatikan input dan proses, dan juga pada penilaian autentik ini tidak hanya mengukur aspek kognitif, akan tetapi juga menilai kemampuan afektif dan psikomotorik (Supardi, 2015).

Pada kurikulum 2013 yang menyangkut tentang pembelajaran Pendidikan Agama Islam, mengacu pada PERMENAG No. 2 tahun 2008 disebutkan empat mata pelajaran dengan kompetensi lulusan dan standar isi sebagai berikut, yaitu (1) Al-Qur'an Hadis; (a) membaca, menghafal, menulis, dan memahami surat-surat pendek dalam Al-Qur'an surat Al-Fatihah, An-Nas sampai dengan surat Ad-Dhuha; (b) menghafal, memahami arti, dan mengamalkan hadis-hadis pilihan tentang akhlak dan amal shalih, (2) Akidah Akhlak; (a) mengenal dan meyakini rukun iman dari iman kepada Allah sampai dengan iman kepada qada dan qadar melalui pembiasaan dalam mengucapkan kalimatkalimat Thayyibah; (b) pengenalan, pemahaman sederhana, penghayatan terhadap rukun iman dan asmaul husna; (c) pembiasaan dalam pengamalan akhlak terpuji dan adab islami serta menjauhi akhlak tercela dalam perilaku sehari-hari, (3) Fikih; (a) mengenal dan melaksanakan huku Islam yang berkaitan dengan rukun Islam mulai dari ketentuan dan tata cara pelaksanaan taharah, salat, puasa, zakat, sampai dengan pelaksanaan ibadah haji; (b) ketentuan tentang makanan dan minuman, khitan, dan kurban; (c) pelaksanaan jual beli dan pinjam meminjam, (4) Sejarah Kebudayaan Islam; (a) mengenal, mengidentifikasi, meneladani, dan mengambil ibrah dari sejarah Arab pra Islam; (b) sejarah Rasulullah SAW dan Khulafaurrasyidin; (c) perjuangan tokoh-tokoh agama Islam di daerah masing-masing (Permenag RI, 2008).

\section{Penilaian Autentik Pada Mata Pelajaran Agama Islam}

Pendidikan Agama Islam dan Budi Pekerti merupakan salah satu mata pelajaran yang wajib dipelajari mulai dari pendidikan dasar hingga pendidikan tinggi. Pendidikan Agama Islam (PAI) bertujuan untuk meningkatkan keimanan, pemahaman, penghayatan, dan pengamalan siswa tentang agama Islam, sehingga menjadi muslim yang beriman dan bertaqwa kepada Allah SWT, serta berakhlak mulia dalam kehidupan pribadi, masyarakat, berbangsa, dan bernegara. Penilaian Pendidikan Agama Islam di sekolah dilakukan terhadap semua aspek. Aspek-aspek pokok penilaian PAI yaitu pengetahuan agama Islam, keterampilan agama Islam, penghayatan agama Islam, dan pembiasaan pengamalan agama Islam (Lubna, 2014).

Penilaian dilakukan tidak hanya dengan tes tertulis atau lisan tetapi juga pengamatan. Pertama, penilaian sikap yaitu penilaian observasi, penilaian sikap diri, dan penilaian teman sebaya. Kedua, penilaian pengetahuan terdiri dari mulai dari penilaian tes lisan, penilaian tertulis, dan penugasan. Ketiga, penilaian keterampilan yang terdiri dari penilaian portofolio, penilaian proyek, dan penilaian 
unjuk kerja. Dalam penerapan penilaian autentik pembelajaran harus dikaitkan dengan masalah keseharian peserta didik. Guru mengaitkan materi dengan keadaan masyarakat. Guru tidak terpaku hanya degan buku teks melainkan kreatif mencari bahan belajar dari koran, majalah, atau internet ( $\mathrm{J}$ Musfah, 2017).

Penilaian autentik sangat baik diterapkan dalam pembelajaran Pendidikan Agama Islam. Dengan adanya penilaian autentik ini guru dapat melatih peserta didik menerapkan secara langsung materi yang diajarkan di kehidupan nyata sekaligus dapat menilai sikap peserta didik setelah belajar materi tersebut. Contohnya pada materi ibadah tentang praktek pengurusan jenazah, mulai dari memandikan, mengafani, mensholatkan, dan menguburkan. Pada materi ini pendidik dapat mengajak peserta didik untuk melakukan praktikum pengurusan jenazah sehingga peserta didik mendapatkan pengalaman langsung dalam pengurusan jenazah, serta mampu menerapkan pengtahuan tentang pengurusan jenazah. Implementasi dari penilaian autentik bukanlah hal yang mudah bagi guru, apalagi jika guru tersebut sudah berumur. Penilaian autentik menuntut guru untuk kreatif, sehingga guru harus menyiapkan instrument penilaian dengan baik. Hal ini dibuktikan berdasarkan hasil penelitian yang dilakukan Astuti bahwa belum efektifnya penerapan penilaian autentik dalam pembelajaran PAI, ketidaksiapan guru karena kurangnya pemahaman terhadap teknis penilaian. Selain itu, kendala guru dalam menerapkan penilaian autentik adalah penyusunan soal yang terlalu banyak, format penilaian yang terlalu rumit membuat guru kerepotan dalam melakukan penilaian kepada setiap peserta didik. Juga terdapat kendala waktu untuk menyusun dan melaksanakan penilaian autentik dirasa kurang cukup (Astuti, 2017). Seharusnya guru siap menggunakan penilaian apapun demi tercapainya tujuan pembelajaran. Guru PAI dituntut untuk menguasai berbagai penilaian, termasuk penilaian autentik, karena guru PAI tidak akan pernah mengetahui secara utuh keberhasilan atau kegagalan dari pembelajaran yang dilaksanakan. Penilaian juga tidak akan bermakna, bila tidak diimbangi dengan kemampuan menganalisis hasil penilaian dan memanfaatkannya sebagai dasar penyusunan program tindak lanjut yang merupakan salah satu fungsi dari penilaian (Lubna, 2014).

Dengan demikian, dapat dikatakan bahwa penilaian autentik ini dapat diterapkan dalam pembelajaran Pendidikan Agama Islam. Hal ini dikarenakan melalui penilaian autentik guru juga dapat mengetahui sejauh mana pemahaman dan kemampuan peserta didik dengan menilai kompetensi sikap, pengetahuan, dan keterampilan peserta didik. Dalam penggunaan penilaian autentik ini guru dianjurkan dapat mengoperasikan komputer karena format penilaian yang menggunakan rubrik. Guru juga harus siap dengan pembuatan format-format penilaian yang digunakan untuk mengevaluasi peserta didik. 


\section{KESIMPULAN}

Dari hasil penelitian yang telah dilakukan menunjukkan penilaian autentik di SDN 1 Bangunrejo Ponorogo terutama pada mata pelajaran Pendidikan Agama Islam dan Budi Pekerti masih kurang maksimal. Hal ini dikarenakan guru masih kurang memahami penilaian autentik dan masih beranggapan bahwa penilaian autentik terlihat rumit. Penilaian autentik membutuhkan banyak persiapan, membutuhkan waktu yang tidak sedikit, serta instrumen penilaian yang rumit. Hal tersebut disebabkan karena belum akuratnya hasil penilaian pada mata pelajaran Pendidikan Agama Islam dan Budi Pekerti SDN 1 Bangunrejo yang membuat ketidaksesuaian antara nilai dengan kompetensi yang dimiliki peserta didik. Contohnya, penilaian pengetahuan guru hanya menggunakan teknik pilihan ganda saja. Seharusnya dalam evaluasi pembelajaran guru dituntut untuk lebih kreatif dalam pemilihan teknik penilaian. Untuk meminimalisir hal tersebut, sebaiknya guru mendapatkan pembekalan lebih maupun sosialisasi mendalam tentang penilaian autentik agar hasil penilaian akurat. Pada kurikulum 2013 ini penilaian autentik sangat diperlukan untuk evaluasi pembelajaran dari ranah pengetahuan, sikap, dan keterampilan siswa. Dengan adanya penilaian autentik ini akan lebih akurat dalam mengetahui berhasil tidaknya tingkat pencapaian kompetensi selama proses pembelajaran berlangsung.

\section{DAFTAR PUSTAKA}

Arifin. (1986). Kapita Selecta Pendidikan Umum dan Agama. Toha Putra.

Astuti, E. . (2017). Problematika Impelementasi Penilaian autentik kurikulum 2013 dalam pembelajaran pendidikan agama islam di SD N Ploso 1 Pacitan. Al-Idaroh, 1(2), 18-41.

Baharudin. (2016). Pengembangan Media pembelajaran PAI Berbasis Lingkungan Melalui Model ASSURE. Cendikia : Journal of Education and Society.

J Musfah. (2017). Manajemen Pendidikan: Teori, Kebijakan, dan Praktik. Kencana.

Kunandar. (2014). Penilaian autentik (penilaian hasil belajar peserta didik berdasarkan kurikulum 2013). PT Raja Grafindo Persada.

Lubna. (2014). Akurasi dan Akutansibilitas Penilaian Kinerja Guru Pendidikan Agama Islam. Ulumuna, 18(1).

Majid, A. (2015). Penilaian Autentik Proses dan Hasil Belajar. PT Remaja Rosdakarya.

Muaizdati, N. (2019). Problematika guru kelas dalam melaksanakan penilaian autentik di SD Hapalah 1 kecamatan Banua lawas kabupaten tabalong. Al-Madrasah: Jurnal Ilmiah Pendidikan Madrasah Ibtidaiyah, 4(1), 103-124. 
Muhadjir Neong. (1996). Metode Penelitian Kualitatif. Rake Surasin.

Muhaimin. (2002). Paradigma Pendidikan Agama Islam (Upaya mengaktifkan pendidikan agama islam disekolah). Rosdakarya.

Mulyasa E. (2006). Kurikulum Tingkat Satuan Pendidikan. Rosdakarya.

Nurhadi. (2004). Kurikulum 2004; pertanyaan dan jawaban. Grassindo.

Oemer, H. (2014). Kurikulum dan Pembelajaran. Bumi Aksara.

Permenag RI Standar Kompetensi Lulusan dan Standar Isi Pendidikan Islam di Madrasah Lampiran 1. (2008).

Pusat Informasi Balitbang Depdiknas. Undang-Undang Sisdiknas No.2 Tahun 2003. (2003). Sinar Grafika.

Retnawati, H. (2017). Menyusun Laporan hasil Asesmen pendidikan di Sekolah Referensi Untuk Pendidik, Mahasiswa, dan Praktisi Pendidikan. UNY Press.

Sugiyono. (2017). Metode Penelitian Kuantitatif dan $R \& D$. Alfabeta.

sukiman. (2003). Modul Penilaian Pembelajaran. PLPGFITK.

Supardi. (2015). Penilaian Autentik Pembelajaran Afektif, Kognitif dan Psikomotorik (Konsep dan Aplikasi). Rajawali Pers.

Tiara, Shintia tiara, E. (2019). Analisis Penilaian Sikap Sosial dalam Penerapan Kurikulum 2013 di SD N 1 wATULIMO. Eduhumaniora : Jurnal Pendidikan Dsara, 2(1), 21-30.

Uno B Hamzah, K. S. (2012a). Assesment Pembelajaran. Bumi Aksara.

Uno B Hamzah, K. S. (2012b). Assesment pembelajaran. Bumi Aksara.

Winarni, S. E. (2017). Persepsi Guru PAI dan Praktek Penilaian Sikap pada Kurikulum 2006 dan Kurikulum 2013. Mukaddimah : Jurnal Studi Islam, 2(1), 95-114. 
IMPLEMENTASI PENILAIAN AUTENTIK KURIKULUM 2013 PADA MATA PELAJARAN PAI DAN ...

Mukhlas Habibi, Fina Aulika Lestari, Yusmicha Ulya Afif 